\title{
Õpilasfirmade programmi mõju noorte sotsiaalsetele oskustele
}

\author{
Katrin Saks ${ }^{\mathrm{a}}$, Janeli Virnas ${ }^{\mathrm{a}}$ \\ ${ }^{a}$ Tartu Ülikooli haridusteaduste instituut
}

\begin{abstract}
Annotatsioon
Uurimuse eesmärk on välja selgitada, milline on õpilasfirmade programmi roll noorte sotsiaalsete oskuste ja isiksusomaduste arendamisel. Uuring tehti 2016.-2017. aastal õpilasfirmade programmis osalenud noortega, kes olid pärit Tartu-, Põlva- ja Võrumaalt. Eel- ja järeltestimise käigus koguti enesekohase küsimustikuga andmeid sotsiaalsetele oskustele ja ettevõtlikkusega seotud olulisimatele isiksusomadustele antud hinnangute kohta. Tulemustest selgus, et õpilasfirmade programmis osalemine toetab noorte hinnangul nende enesejuhtimisoskust, akadeemilisi oskusi ja enesekehtestamisoskust ning ettevõtlikkuse, loovuse ja paindlikkuse arengut. Statistiliselt olulised muutused avaldusid vaid Põlva- ja Tartumaa noortel, kellele pakuti peale õpilasfirmade üldise programmi ka lisategevusi ja -tuge. Võrumaa noorte hinnangul ei avaldunud nende sotsiaalsete oskuste ja isiksusomaduste arengus suuri muutusi, mille põhjus võib olla liiga suur õpilaste arv ühe juhendaja kohta. Samuti ei olnud Võrumaa õpilasfirmadel kaasatud õppesse mentoreid ning nad ei osalenud toetavates tegevustes.
\end{abstract}

Võtmesõnad: õpilasfirmad, sotsiaalsed oskused, isiksusomadused

\section{Sissejuhatus}

Noorte tööhõive probleemid, mis on üha teravamalt päevakorda kerkinud, on kaasa toonud arutelud koolis omandatavate oskuste üle. 21. sajandi oluliste oskuste hulka kuuluvad loomingulisus ja probleemilahendusoskus, sotsiaalsed oskused, iseseisvus ja ettevõtlikkus. Inimese ettevõtlikkust käsitletakse sageli koos tema sotsiaalse pädevusega (Chazan, Laing, Davies, \& Phillips, 2001). Sotsiaalsed oskused on nii ettevõtlikkus- ja ettevõtluspädevuse kui ka aktiivseks ühiskonnaliikmeks kasvamise eeldus. Sotsiaal-emotsionaalne kompetentsus 
ja selle tuumkompetentsid, eriti positiivsete suhete loomine, keeruliste olukordade lahendamine ning vastutuse võtmine otsuste tegemisel (Zhou \& Ee, 2012) võivad ettevõtlusega seotud olukordades olla määrava tähtsusega. Ka sotsiaalsete oskuste teooriad (Caldarella \& Merrell, 1997; Gresham \& Elliot, 1993; Walker, Colvin, \& Ramsey, 1995) käsitlevad mitmesuguseid ettevõtlikkusega seotud oskusi.

Tööturule sisenemisel peetakse sotsiaalseid oskusi väga vajalikeks ning heade sotsiaalsete oskustega inimesed on töökohal kõrgelt hinnatud (Keltikangas-Järvinen, 2011). Seetõttu ongi möödapääsmatu leida võimalusi toetada nii formaalhariduses, ettevõtlusõppes kui ka õpilasfirmade programmides ettevõtlikkuspädevuse ja muude oskuste hulgas noorte sotsiaalsete oskuste arengut.

Õpilasfirmade programm on üldhariduskooli kolmanda kooliastme ja gümnaasiumi tarbeks loodud programm, mille eesmärk on toetada noorte ettevõtlikkuse kui hoiaku ja ettevõtlusoskuste kujunemist. Programm on laialt levinud nii Euroopas kui ka Ameerikas. Eestis alustati sellega 1992. aastal. Õpilasfirmade programmi kohta on tehtud ka mitmeid uuringuid. Et hinnata õpilasfirmade tegevuse tulemuslikkust, on Inglismaal uuritud noorte kutsealast konkurentsivõimet ning noorte teadlikkust oma võimetest ja potentsiaalist (Young Enterprise, 2015), Taanis aga noorte soovi panustada ühiskonda ja tööalast ambitsioonikust (Vestergaard, Moberg, \& Jørgensen, 2012). Ettevõtlusõppeuuringud on näidanud, et noored on nõus osalema aktiivsemalt kooli ja kogukonna tegevustes ning neil on selgem arusaam oma rollist ühiskonnas. Ettevõtlusõppe ja õpilasfirmade programmi läbinud noortel on suurenenud ettevõtlikkusteadlikkus ning nad mõistavad paremini vastutuse võtmise olulisust. Noored oskavad teadlikumalt analüüsida ja kasutada oma oskusi ning nad suudavad neid rakendada väärtuste loomisel (ibid.). Kuigi õpilasfirmade mõju noorte arengule on pälvinud uurimustes suurt tähelepanu (Virnas, 2017), ei ole autoritele teadaolevalt seni uuritud ettevõtlusõppe mõju nende sotsiaalsetele oskustele.

Kuna sotsiaalsed oskused täidavad tähtsat osa ettevõtlikkuspädevuse arendamisel ja toetamisel (Chazan et al., 2001), seati uurimuse eesmärgiks välja selgitada õpilasfirmade programmi mõju noorte sotsiaalsete oskuste arengule. Eesmärgist lähtudes sõnastati järgmine uurimisküsimus: milline on õpilasfirmade programmi mõju noorte sotsiaalsetele oskustele ja ettevõtlikkusega seotud isiksusomadustele? 


\section{Sotsiaalsete oskuste mõiste, klassifikatsioonid ja mõõtmine}

Kuna erialane teaduskirjandus ei paku ühtset definitsiooni sotsiaalsete oskuste kohta, siis siinse uurimuse raames piiritletakse sotsiaalsete oskuste mõiste nende määratlustega, mis on otseselt seotud ettevõtlikkusega. Walker jt (1995) defineerivad sotsiaalseid oskusi selliste kompetentside kogumina, mis soodustavad eakaaslastepoolset aktsepteerimist, aitavad algatada ja hoida positiivseid suhteid ning võimaldavad efektiivselt kohaneda suuremas sotsiaalses keskkonnas. Greshami ja Ellioti (1993) käsituse kohaselt peetakse sotsiaalseteks oskusteks sotsiaalselt aktsepteeritud õpitud oskusi, mis võimaldavad indiviidil suhelda teiste inimestega viisil, mis kutsub esile positiivseid reaktsioone ja aitab vältida negatiivseid. Selle järgi vaadeldakse sotsiaalseid oskusi täiskasvanute, näiteks õpetajate ja lapsevanemate seisukohast lähtudes (ibid.).

Erinevused sotsiaalsete oskuste käsitlustes on toonud kaasa ka mõnevõrra erinevad klassifikatsioonid. Praeguses uuringus lähtuti Caldarella ja Merrelli (1997) taksonoomiast, mille kohaselt on sotsiaalsetel oskustel viis dimensiooni: suhted eakaaslastega, enesejuhtimine, akadeemilised oskused, kuuletumine ja enesekehtestamisoskused. Järgmised lühikirjeldused aitavad avada nende alamkonstruktide sisu (Caldarella \& Merrell, 1997; Saat, 2005):

a. suhted eakaaslastega (peer relations): oskus öelda ja vastu võtta komplimente, abi pakkumine, vabanduse palumine, kaaslaste eest seismine (kaitsmine), osalemine ühistes tegevustes, osalemine vestlustes, juhtimisoskuste omamine, tundlikkus kaaslaste tunnete suhtes (empaatia, sümpaatia), huumorimeel, sõprussuhete loomine ja hoidmine;

b. enesejuhtimine (self-management): oskus probleemide ilmnemisel rahulikuks jääda, oskus kontrollida oma käitumist tugevate emotsioonide (nt viha) korral, koostöö eri situatsioonides, kriitika talumine, reeglite ja piirangute järgimine, konfliktide korral oskus minna kompromissile, narrimise ignoreerimine või sellele kohaselt reageerimine;

c. akadeemilised oskused (academic skills): juhendaja juhiste kuulamine ja täitmine, iseseisvus ülesannete täitmisel/lõpetamisel, individuaalsete tööülesannete täitmine oma võimete tasemel, vaba aja mõistlik kasutamine, käitumine organiseeritult (vajalikud õppevahendid kaasas, õigeaegne kohaletulek), oskus küsida vajaduse korral abi, oskus küsimusi esitada, oskus ignoreerida kaaslaste mõjutusi (tegevuse jätkamine hoolimata sellest, et kaaslased segavad);

d. kuuletumine (compliance): instruktsioonidest ja juhenditest kinnipidamine, reeglite järgimine, vaba aja mõistlik kasutamine, enda asjade jagamine teistega, kriitikale ja märkustele kohaselt reageerimine, määratud ülesande täitmine ning lópule viimine, töövahendite koristamine; 
e. enesekehtestamisoskused (assertion skills): initsiatiivi näitamine teistega suhtlemiseks, komplimentide tunnustamine, tegevuste alustamine, teiste kaasamine tegevustesse, enda kohta positiivse esiletoomine, enesekindlus, sõbrunemine, ebaõigete reeglite ja toimingute vaidlustamine (ei ütlemine), enda esitlemine võõrastele, usalduslikkus suhtlemisel vastassugupoolega, ülekohtule reageerimine.

Sotsiaalsed oskused ei arene iseenesest, vaid õppimisprotsessi kaudu (Tropp \& Saat, 2010). Sotsiaalsete oskuste õpetamine on oluline igal haridusastmel ja peaks algama juba varajases lapsepõlves. Põhikooli- ja gümnaasiumiseaduses (2010) on nimetatud üldhariduskooli alusväärtused, mille hulka kuulub üldhariduskooli kohustus toetada õpilaste sotsiaalset arengut. Gümnaasiumi riiklikus õppekavas (2011) on üldpädevuste all sätestatud sotsiaalsete oskustega seotud pädevused: 1) sotsiaalne pädevus, millena mõistetakse muu hulgas suutlikkust ,... ennast teostada; toimida aktiivse, teadliku, abivalmi ja vastutustundliku kodanikuna, ... teha koostööd teiste inimestega erinevates situatsioonides; aktsepteerida inimeste ja nende väärtushinnangute erinevusi ning arvestada neid suhtlemisel ..."; 2) enesemääratluspädevus, mille raames soovitakse arendada suutlikkust „... mõista ja hinnata adekvaatselt oma nõrku ja tugevaid külgi, arvestada oma võimeid ja võimalusi; analüüsida oma käitumist erinevates olukordades ..."; 3) suhtluspädevus, mille kaudu arendatakse suutlikkust „... ennast selgelt, asjakohaselt ja viisakalt väljendada ..., arvestades olukordi ja mõistes suhtluspartnereid; ... ennast esitleda, oma seisukohti esitada ja põhjendada ...."

Greshami ja Ellioti (1993) järgi on sotsiaalsete oskuste areng üks olulisimaid õpiprotsessi väljundeid. Peale akadeemilise õpetamisviisi on võimalik sotsiaalseid oskusi õpetada ka kogemuslikult, näiteks kogemus- ja aktiivõppemeetodite abil. Sel juhul jõutakse sotsiaalsete oskuste arendamiseni kogemise ja avastamise kaudu, luues seoseid eri eluvaldkondade vahel (Ploom-Zilmer, 2013). Siinse uurimuse fookuses olev õpilasfirmade programm on aktiivõppe praktiline väljund ettevõtlus- ja majandusõppes.

\section{Ettevõtlusõpe ja õpilasfirmad}

Ettevõtlikkus on hoiak, mis viitab inimese võimele muuta mõtted tegudeks. See eeldab riskivalmidust, uuendusmeelsust, loomingulisust ning oskust tunda ära võimalusi, kavandada mitmesuguseid tegevusi ja ka kavandatut ellu viia. Ettevõtlik inimene saab iseendaga edukalt hakkama ja ta on suuteline muutma ühiskonda eri elualadel nii vabatahtliku, ettevõtja kui ka ametnikuna (Ettevõtlusõppe edendamise kava ..., 2010). 
Ettevõtlikkuse arendamisel on tähtis panustada aktiivselt ettevõtlusõppesse eri haridustasemetel (Eesti ettevõtluse ..., 2013). Ettevõtlusõppe üldine eesmärk on suurendada nende inimeste hulka, kes tahavad ja suudavad oma ideid realiseerida nii enda, kogukonna kui ka ettevõtte tasandil. Ettevõtlusõppe sisu määramisel tuleb arvestada järgmiste oluliste teguritega: ettevõtlikkus kui hoiak, isiksusomadused, teadmised ning oskused. Ettevõtlusõppe alustaladeks võib pidada isiksusomaduste, hoiakute ja oskuste kujundamist, mis aitab suurendada inimese võimekust võimaluste märkamisel ja realiseerimisel ning tema teadmisi ja oskusi idee edukaks teostamiseks (Ettevõtlusõppe edendamise kava ..., 2010).

Haridusel on täita suur osa suhtumise kujundamisel ja oskuste omandamisel, samuti kultuuris laiemalt. Ettevõtlusharidus ühendab eri komponente, sisaldades nii praktilist õpet, oskuste omandamist kui ka mõtteviisi muutust. Seos ettevõtlikkuse ja innovatsiooni avaldumise aja ning ettevõtluses karjääri tegemise vahel näitab, et mida varem ettevõtlikkus ja uuenduslikkus avalduvad, seda tõenäolisemalt teeb noor tulevikus ettevõtluse valdkonnas karjääri (Wilson, 2008).

Ettevõtlusõppe rahvusvaheline töörühm rõhutab oma aruandes, et ettevõtlusõpe peaks sisaldama kaht olulist elementi: suuremat teadlikkust ettevõtlikest hoiakutest ja oskustest (hõlmab isiksusomaduste arendamist, kuid ei ole seotud ettevõtte loomisega) ning ettevõtlusega alustamise kursust. Eelnevast lähtudes tuleks ettevõtlusõpet rakendada eri haridusastmetel, pidades silmas järgmist (Final report ..., 2004):

1) ettevõtlikkusega seotud isiksusomaduste arendamine, sh loovus, algatusvõime, riskivalmidus ja vastutustunne;

2) varajane kontakt ärimaailmaga ja arusaam ettevõtjate rollist ühiskonnas;

3) õpilaste teadlikkus ettevõtlusest kui karjäärivõimalusest (arusaam, et peale töötajaks olemise on võimalik olla ka ise ettevõtja);

4) mitmesugused praktilised tegevused (learning by doing), sh õpilasfirmade programm ja virtuaalsed firmad;

5) ettevõtlusega alustamist käsitlevate koolituste pakkumine (eriti oluline on see kutse- ja ülikoolide tasandil).

Õpilasfirma programm meenutab oma ülesehituselt alustava ettevõtjana tegutsemist. See kestab ühe õppeaasta, mille vältel õpilased tegelevad toote või teenuse arendamise ja turustamisega ning läbivad seega 8-9 kuu jooksul kompaktselt ettevõtlusega alustamise etapid (joonis 1). 


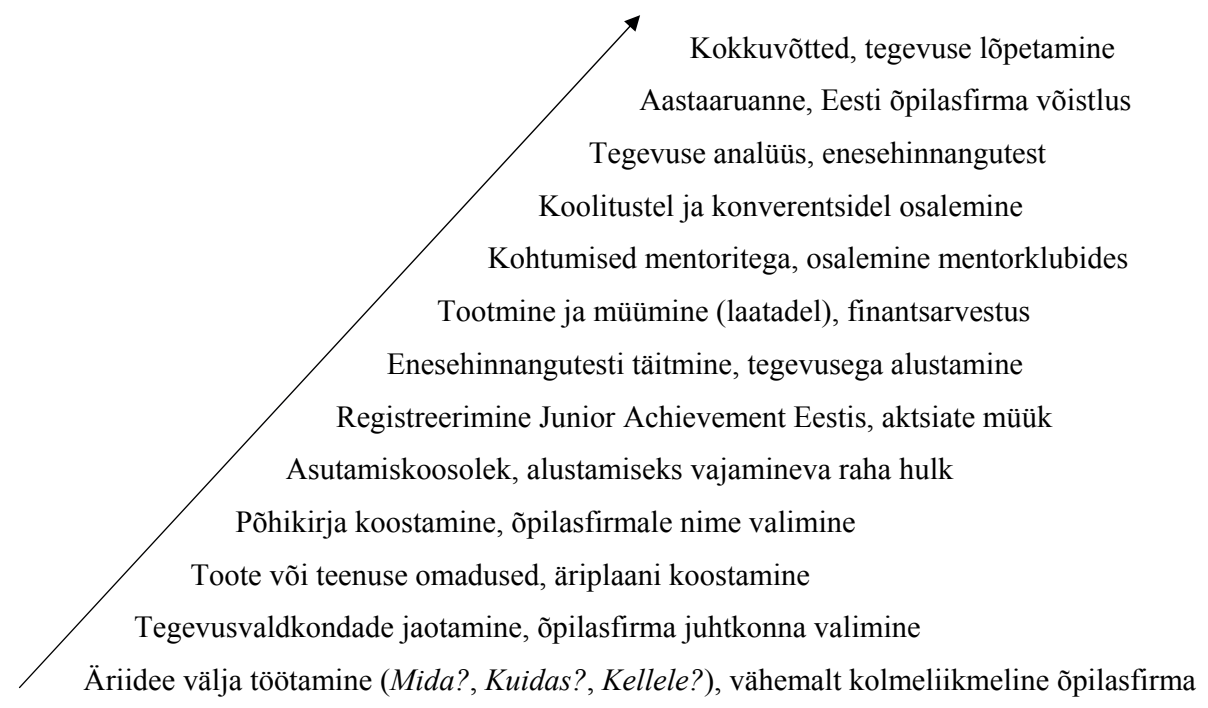

Joonis 1. Õpilasfirma tegevuse trepp (Virnas, 2017)

Osaledes õpilasfirmade tegevuses, on noorel võimalik ennast proovile panna juba kooliajal ja saada vastus küsimusele, kas ettevõtlus võiks olla temale sobilik eluvaldkond. Kuna õpilasfirmat ametlikult äriregistrisse ei kanta, siis ei pea õpilasfirma asutajad olema täisealised. Siiski on õpilasfirma eesmärk pakkuda õppijale reaalse ettevõtte loomisega võimalikult sarnast kogemust. Õpilasfirmade liikmed saavad omandada teadmisi nii majandusõppe tundides kui ka koolitustel. Õpilasfirma tegevuse käigus seostavad noored saadud teadmisi reaaleluliste olukordadega ja näevad, kuidas õpitud teadmised võivad neile praktilises tegevuses kasuks tulla.

Tegevuskavas „Ettevõtlus 2020“, mille keskmes on ettevõtlikkuse taaselavdamine Euroopas, sätestatakse, et igal haridussüsteemist väljunud noorel peaks olema vähemalt üks praktiline ettevõtlusõppe kogemus, ja peetakse oluliseks, et ettevõtlusõppealane haridus oleks kaasatud riiklikesse õppekavadesse, seda eelkõige õpilasfirmade loomise ja keskkooli lõpetamisele eelnenud kohustusliku praktika kaudu (Tegevuskava ..., 2013). Õpilasfirma loomine on koolidele üks kättesaadavaimaid ja efektiivseimaid viise pakkuda praktilise ettevõtlusõppe kogemust. Hinnanguliselt on praegu praktilise ettevõtlusõppe kogemuse omandamise ja ligipääsu võimalus ühel noorel kümnest (Eide \& Olsvik, 2017).

Õpilasfirma programmi eesmärk on võimaldada õppijatel omandada praktilise tegevuse kaudu ettevõtlusteadmisi ja arendada oma ettevõtlikkust. Õpilasfirma tegevuse alaeesmärgid on järgmised: ettevõtte elutsükli läbimine ettevõtja ja juhi rollis, rühmatööoskuste ja loovuse arendamine, vastutustunde 
kasvatamine, aja planeerimise õppimine, uurimistöö (turu-uuringu) tegemise, esitlemis- ja suhtlemisoskuste arendamine (Eide \& Olsvik, 2017).

Õpilasfirmade programmi mõju on uuritud eelkõige ettevõtlikkuse vaatepunktist. 2016. aastal viies Euroopa riigis (Eesti, Läti, Itaalia, Soome ja Belgia) tehtud uuring näitab, et õpilasfirmade programmi läbinud noortel paranevad tulemused kolmes kategoorias: teadmistes, nt firma loomine ja juhtimine; oskustes, nt loovus, probleemide lahendamine, esitlemine; ning suhtumises, nt motivatsioon, vastutustunne, enesetõhusus ja -kindlus (Eide \& Olsvik, 2017). Igal aastal Inglismaal korraldatavad uuringud õpilasfirmade programmi mõju kohta osutavad aga kompetentsi kasvule järgmistes kategooriates: probleemide lahendamine, finantsvõimekus, suhtlemine, initsiatiivikus, organisatoorsed oskused, enesekindlus, paindlikkus, enesest lugupidamine, eesmärgistatus, ambitsioonikus, karjäärivõimekus (Young Enterprise, 2016).

Kuna järjest enam hindavad tööandjad ettevõtlikke ja loovaid inimesi, siis kindlasti pakub õpilasfirma kogemus väärtust ka tööturule sisenemisel. Õpilasfirma programmis osalemisest on võimalik õppida ja kasu saada igas vanuses noorel. See aitab arendada mitmesuguseid oskusi, mis tulevad kasuks tööturule sisenemisel, ning annab ühtlasi väärtusliku koostöökogemuse. Programmis osaledes saavad noored õppida meeskonnatööd, suhtlemisoskust, ideede esitlemist, toimetulekut ebakindluse ja ebaõnnestumistega, oskust analüüsida saadud kogemust ning pöörata ebaõnnestumised positiivseteks õppetundideks. Kõik need omandatud oskused on tulevikus kasulikud nii ettevõtlusmaastikul kui ka palgatöötajana tegutsedes, lisaks toetavad need kõikide teiste ainete õppimist koolis (Ettevõtlusõppe edendamise kava ..., 2010).

\section{Metoodika}

\section{Valim}

Uuringu valimisse kuulusid kolme Lõuna-Eesti maakonna - Põlva-, Tartu- ja Võrumaa - õpilasfirmade programmis osalevad gümnaasiumiastme noored (10.-12. klass). Junior Achievementi andmetel oli eeltestimise lõppedes 2016. aasta detsembri seisuga õpilasfirmade programmiga kõnealuses piirkonnas liitunud 138 noort. Esimeses ankeetküsitluses osales 117 noort. Järelküsitluse ajaks oli programmiga liitunuid 221, kellest osales küsitluses 112. Mõlemas küsitluses osales 94 noort, mis teeb $43 \%$ üldkogumist. Lõplikuks valimiks kujuneski 94 õpilast: Põlvamaalt 21, Tartumaalt 30 ja Võrumaalt 43 õpilast (joonis 2). Nende vastused olid edaspidise andmeanalüüsi aluseks. Valimi sooline koosseis oli 58 tüdrukut $(61,7 \%)$ ja 36 poissi (38,3\%). Vastajate keskmine vanus oli 17,01 aastat $(S D=0,31)$. 


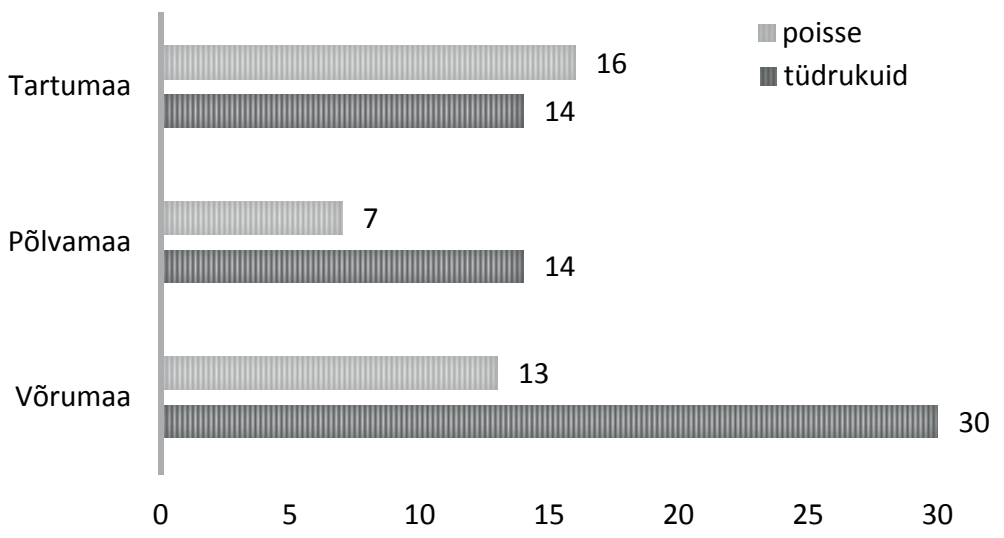

Joonis 2. Valimi sooline jaotus maakondade kaupa

\section{Mõõtevahend}

Uuring tehti kvantitatiivsete meetoditega. Eel- ja järeltestimiseks töötati välja Likerti skaalal põhinev enesekohane küsimustik, mis lähtub Caldarella ja Merrelli (1997) sotsiaalsete oskuste raamistikust ning nende loodud klassifikatsioonist. Küsimustiku tõlkis eesti keelde artikli teine autor (vt lisa).

Uuringus kasutatud küsimustik koosneb 39 küsimusest ja jaguneb kolme ossa. Esimene osa sisaldab küsimusi objektiivsete tunnuste kohta, milleks on vastaja sugu, vanus ja maakond. Teises osas on 29 enesekohast väidet, mis jaotuvad viide faktorisse: suhted eakaaslastega, enesejuhtimine, akadeemilised oskused, kuuletumine ja enesekehtestamisoskused (tabel 1). Kolmandas osas on küsimused, kus vastaja saab viiepalliskaalal hinnata oma isiksusomadusi: ettevõtlikkust, loovust, uuendusmeelsust, paindlikkust, enesekindlust, vastutustunnet ja sihikindlust. Isiksusomaduste valiku aluseks oli õpilasfirmade programmi juurde kuuluv enesehinnangutest (The Entrepreneurial Skills Pass), mis on Euroopa riikides õpilasfirmade programmi läbimise kohustuslik osa ning mida täidavad kõik programmi läbivad noored õpilasfirmaga alustades ja lõpetades.

Vastajad hindasid oma sotsiaalseid oskusi ja isiksusomadusi skaalal 1-5: 1 - „see ei ole minu puhul õige“, 2 - „vahel harva kehtib minu puhul“, 3 „mõnikord kehtib minu puhul“, 4 - „sageli kehtib minu puhul“, 5 - „on minu puhul väga õige“. Et olla kindel kasutatud mõõdiku reliaabluses, kontrolliti eeltesti tulemuste põhjal küsimuste kooskõla Cronbachi alfaga (tabel 1). 
Tabel 1. Mõõtevahendi faktorite sisemise reliaabluse näitajad

\begin{tabular}{lcc}
\hline Faktorid & Cronbachi alfa & Väidete arv faktoris \\
\hline Suhted eakaaslastega & 0,744 & 6 \\
\hline Enesejuhtimine & 0,763 & 6 \\
\hline Akadeemilised oskused & 0,769 & 6 \\
\hline Kuuletumine & 0,727 & 3 \\
\hline Enesekehtestamisoskused & 0,870 & 8 \\
\hline Terve küsimustik & 0,931 & 29 \\
\hline
\end{tabular}

Suhteliselt head faktorite reliaabluse näitajad lubavad järeldada, et tegemist on reliaabli mõõtevahendiga. Küsimustiku valideerimise eesmärgil tehti kinnitav faktoranalüüs suurima tõepära meetodiga, mis andis mudeli headuse indeksiteks CMIN/DF $=1,713\left(\chi^{2}=616,624 ; d f=360\right), \mathrm{CFI}=0,83$, RMSEA $=0,071$.

Küsimustik koostati LimeSurvey keskkonnas ning andmeid koguti elektroonselt. Küsimustiku aadress edastati uuringus osalevatele õpilastele, kes täitsid küsimustiku iseseisvalt oma vabal ajal.

\section{Uuringu protseduur}

Eeltestimine korraldati õpilasfirmade programmiga liitumise alguses oktoobris-novembris 2016. Seejärel läbisid noored kolme-nelja kuu jooksul mitmesuguseid programmiga seotud tegevusi ja pärast seda toimus järeltestimine. Eel- ja järeltestimise vahel tehti õpilasfirmade programmi raames järgmisi tegevusi: arendati ja turundati toodet/teenust ning osaleti laatadel ja koolitustel. Kohtumisi korraldati nii meeskonna sees kui ka õpilasfirma juhendajatega. Järeltestimine toimus veebruaris-märtsis 2017.

\section{Andmeanalüïs}

Andmeanalüüsi käigus kasutati kirjeldavat ja võrdlevat statistikat. Kuna vastuste jaotus vastas normaaljaotusele, siis rakendati maakonnapõhiste rühmade erinevuste väljaselgitamiseks ANOVA analüüsi. Õpilasfirmade programmi mõju hindamiseks võrreldi sotsiaalsete oskuste keskmisi $t$-testi alusel. Andmeanalüüsiks kasutati tarkvaraprogramme MS Excel ja SPSS 24. 


\section{Tulemused}

Kuna uuringu mõõtevahendina kasutati enesekohast küsimustikku, siis kõik allpool esitatud tulemused põhinevad vastajate endi hinnangul oma tegevusele ja isiksusomadustele. Et selgitada välja võimalikud erinevused kolme maakonna õpilaste sotsiaalsetes oskustes ja ettevõtlusega seotud isiksusomadustes uuringu alguses, võrreldi neid eeltesti tulemuste põhjal. Kuna ANOVA ei näidanud statistiliselt olulisi erinevusi mitte ühegi sotsiaalsete oskuste faktori ega isiksusomaduse puhul, võib öelda, et õpilasfirmade programmi alguses ei erinenud nende maakondade õpilased oma sotsiaalsetelt oskustelt ega ettevõtlusega seotud isiksusomadustelt.

Et leida, kas ja kui palju toetas osalejate hinnangul esimesel poolaastal läbitud õpilasfirmade programm nende sotsiaalsete oskuste arengut, võrreldi eelja järeltesti tulemusi paariviisilise $t$-testi abil. Tulemustest nähtub, et statistiliselt olulised muutused ilmnesid noorte enesejuhtimise, akadeemiliste oskuste ja enesekehtestamisega seotud sotsiaalsete oskuste arengus (tabel 2).

Tabel 2. Muutus noorte sotsiaalsete oskuste arengus eel- ja järeltesti tulemuste põhjal $(N=94)$

\begin{tabular}{lccccc}
\hline Faktor & $\begin{array}{c}\text { Eeltest } \\
M(\mathrm{SH})\end{array}$ & $\begin{array}{c}\text { Järeltest } \\
M(\mathrm{SH})\end{array}$ & $\boldsymbol{t}$ & $d f$ & $p$ \\
\hline Suhted eakaaslastega & $4,11(0,554)$ & $4,13(0,573)$ & $-0,423$ & 93 & 0,673 \\
\hline Enesejuhtimine & $4,03(0,556)$ & $4,13(0,568)$ & $-2,122$ & 93 & $0,037^{*}$ \\
\hline Akadeemilised oskused & $4,01(0,565)$ & $4,12(0,566)$ & $-2,063$ & 93 & $0,042^{*}$ \\
\hline Kuuletumine & $4,05(0,644)$ & $4,10(0,646)$ & $-0,682$ & 93 & 0,497 \\
\hline Enesekehtestamisoskused & $3,81(0,661)$ & $3,94(0,705)$ & $-2,469$ & 93 & $0,015^{*}$ \\
\hline
\end{tabular}

Märkus. ${ }^{*} p<0,05$.

Isiksusomaduste analüüs osutas statistiliselt olulisele muutusele samuti kolmes kategoorias: loovuses, paindlikkuses ja sihikindluses (tabel 3). 
Tabel 3. Muutus noorte isiksusomaduste arengus eel- ja järeltesti tulemuste põhjal $(N=94)$

\begin{tabular}{lccccc}
\hline $\begin{array}{l}\text { Isiksusomadustega seotud } \\
\text { oskused }\end{array}$ & $\begin{array}{c}\text { Eeltest } \\
M(S D)\end{array}$ & $\begin{array}{c}\text { Järeltest } \\
M(S D)\end{array}$ & $\boldsymbol{t}$ & $d f$ & $\boldsymbol{0}$ \\
\hline Ettevõtlikkus & $3,52(0,800)$ & $3,60(0,807)$ & $-1,068$ & 93 & 0,288 \\
\hline Loovus & $3,56(0,811)$ & $3,74(0,879)$ & $-2,443$ & 93 & $0,016^{*}$ \\
\hline Uuendusmeelsus & $3,60(0,794)$ & $3,73(0,778)$ & $-1,653$ & 93 & 0,102 \\
\hline Paindlikkus & $3,67(0,835)$ & $3,89(0,740)$ & $-2,834$ & 93 & $0,006^{*}$ \\
\hline Enesekindlus & $3,60(0,943)$ & $3,67(0,932)$ & $-0,881$ & 93 & 0,381 \\
\hline Vastutustunne & $4,04(0,891)$ & $4,04(0,994)$ & 0,000 & 93 & 1,000 \\
\hline Sihikindlus & $4,24(0,772)$ & $4,07(0,995)$ & 2,141 & 93 & $0,035^{*}$ \\
\hline
\end{tabular}

Märkus. ${ }^{*} p<0,05$.

Kuna eeltesti tulemustes ei ilmnenud statistiliselt olulisi erinevusi maakondade õpilaste vahel mitte ühegi faktori puhul, siis võimaldas see uurida, kas õpilasfirmade programm avaldas mõju noorte sotsiaalsete oskuste arengule eri maakondade arvestuses. Paariviisilise $t$-testi tulemustest selgus, et statistiliselt olulised erinevused Tartumaa õpilastel olid enesejuhtimise ja akadeemiliste oskustega seotud sotsiaalsete oskuste vahel: enesejuhtimine $-t(29)=-3,19$, $p=0,003$ (eeltestis $M=4,06, S H=0,61$ ja järeltestis $M=4,29, S H=0,61$ ) ja akadeemilised oskused $-t(29)=-2,6, p=0,014$ (eeltestis $M=3,98, S H=0,52$ ) ja järeltestis $M=4,21, S H=0,53$ ) (joonis 3 ). $t$-testi tulemused Põlvamaa noorte puhul näitasid, et olulised erinevused olid akadeemiliste oskuste ja enesekehtestamisega seotud sotsiaalsete oskuste vahel: akadeemilised oskused $t(20)=-2,67, p=0,015$ (eeltestis $M=4,09, S H=0,58$ ja järeltestis $M=4,34$, $S H=0,50)$ ja enesekehtestamine $-t(20)=-3,41, p=0,003$ (eeltestis $M=3,70$, $S H=0,67$ ja järeltestis $M=4,0, S H=0,61$ ) (joonis 4). Seega selgus nende kahe makonna tulemustest, et õpilasfirmade programmil on mõju noorte sotsiaalsete oskuste arengule. Ainus maakond, kus statistiliselt olulisi muutusi paariviisilise $t$-testi tulemustes ei esinenud, oli Võrumaa.

$t$-testi abil uuriti ka seda, kas ja kuidas muutusid noorte hinnangul nende isiksusomadused õpilasfirmade programmi lõpuks. Nii nagu sotsiaalsetel oskustel, olid ka isiksusomaduste arengus statistiliselt olulised muutused vaid kahe makkonna - Tartu- ja Põlvamaa - tulemustes. Tartumaa noorte paariviisilise $t$-testi tulemused näitavad, et olulised muutused ilmnesid ettevõtlikkuse, loovuse ja paindlikkuse arengus: ettevõtlikkus $-t(29)=-3,20, p=0,003$ (eeltestis $M=3,27, S H=0,83$ ja järeltestis $M=3,67, S H=0,92$ ), loovus - 
$t(29)=-2,76, p=0,010$ (eeltestis $M=3,57, S H=0,73$ ja järeltestis $M=3,87$, $S H=0,82$ ), paindlikkus $-t(29)=-5,64, p=0,000$ (eeltestis $M=3,37, S H=0,85$ ja järeltestis $M=4,0, S H=0,79)$. Põlvamaa tulemuste põhjal võib öelda, et õpilasfirmade programm toetas noorte hinnanguid loovuse ja uuendusmeelsuse arengu kohta: loovus $-t(20)=-2,91, p=0,009$ (eeltestis $M=3,57, S H=0,81$ ja järeltestis $M=4,0, S H=0,78)$, uuendusmeelsus $-t(20)=-3,99, p=0,001$ (eeltestis $M=3,43, S H=0,68$ ja järeltestis $M=3,95, S H=0,81$ ). Ka isiksusomaduste arengus ei ilmnenud Võrumaa noortel nende hinnangul statistiliselt olulisi muutusi.

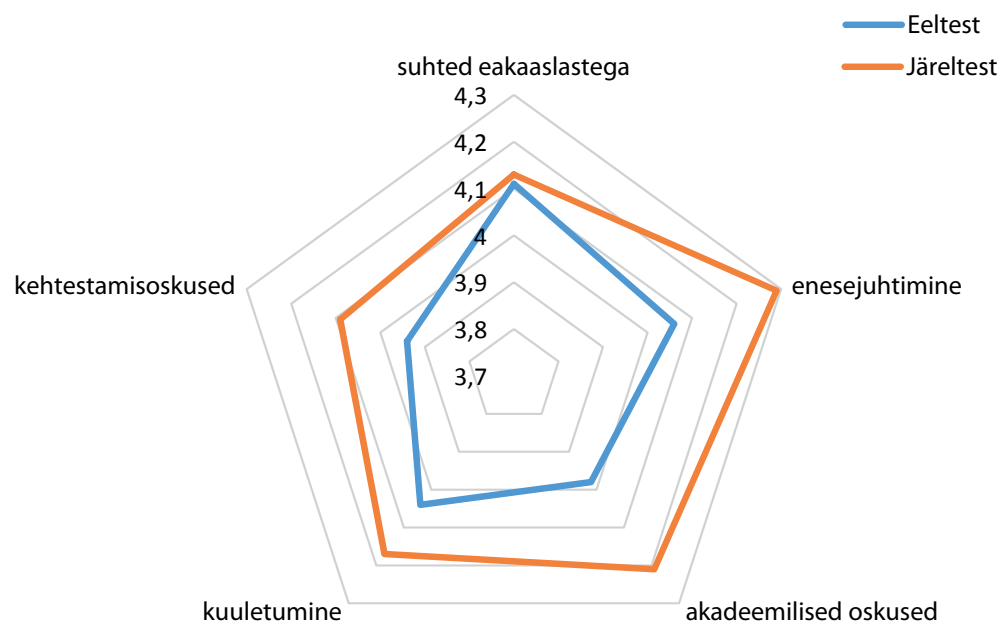

Joonis 3. Sotsiaalsete oskuste areng Tartumaa noortel

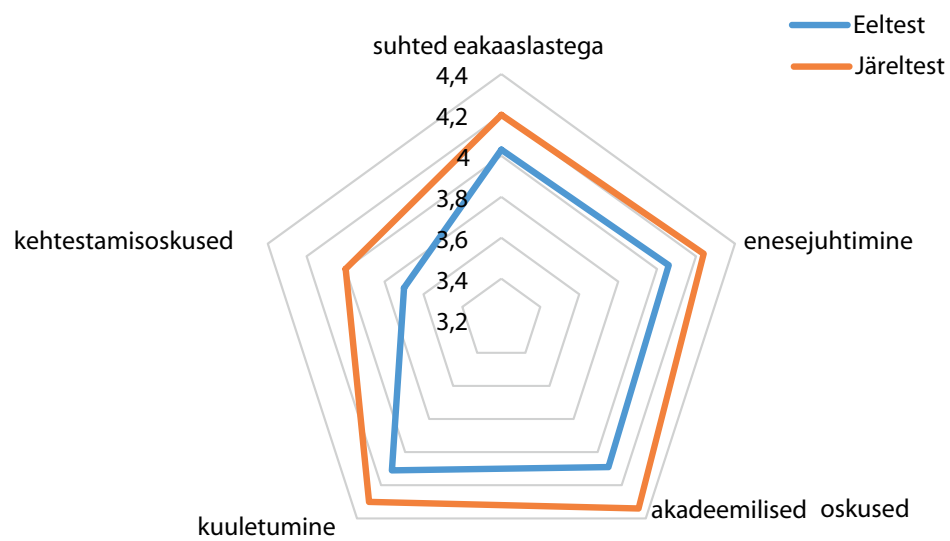

Joonis 4. Sotsiaalsete oskuste areng Põlvamaa noortel 
Seega, uuringu tulemused näitavad õpilasfirmade programmi võimekust toetada noorte sotsiaalsete oskuste arengut. Selle üle, miks sotsiaalsed oskused ei paranenud kõigis vaatlusalustes maakondades, arutletakse järgmises peatükis.

\section{Arutelu}

Eri uurimustes on vaadeldud noorte ettevõtlikkusega seotud oskuste arengut, kuid autoritele teadaolevalt pole noorte ettevõtlusprogrammidel (sh õpilasfirmade programmil) põhinev sotsiaalsete oskuste areng uurijate tähelepanu seni pälvinud. Küll aga käsitletakse sotsiaalseid oskusi kirjeldavates uurimustes mitmeid ettevõtlikkusega seotud oskusi (Gresham \& Elliot, 1993; Walker et al., 1995). Siinse uurimuse eesmärk on analüüsida, kas ja mil määral toetab Junior Achievementi koordineeritav õpilasfirmade programm noorte sotsiaalsete oskuste arengut.

Uurimistulemustest selgus, et õpilasfirmade programmis osalemine tõi kaasa muutused enesekehtestamise ja -juhtimisega seotud oskustes ning akadeemilistes oskustes. Tulemused erinesid mõnevõrra maakonniti. Kuigi õpilasfirmade programmi juhendajad läbivad ühtse koolituse ja üldjoontes on õpilasfirmade programmi juhendamine sarnane, võib siiski esineda erinevusi juhendajate lähenemisviisides ja prioriteetides. Lisaks on nii noortel kui ka nende juhendajatel õpilasfirmades tegutsedes erinev motivatsioon ning maakonniti eri arengu- ja tegutsemisvõimalused. Ka viies Euroopa riigis tehtud uuringu tulemustest selgus, et õpetajate ja õpilaste motivatsioon tegutseda ja valmisolek areneda mõjutavad märkimisväärselt õpilasfirmade tegevust ja selle tulemuslikkust (Eide \& Olsvik, 2017). Praeguses töös ei uuritud küll motivatsiooni, keskkonna ja juhendamisega seotud teemasid, kuid see võib olla üks põhjusi, miks maakondlikult on tulemused mõnevõrra erinevad. Kindlasti väärivad need aspektid tähelepanu tulevastes uuringutes.

Põlva- ja Tartumaa noorte tulemuste põhjal võib öelda, et mõlemas maakonnas arenesid enam-vähem ühetaoliselt akadeemilised oskused, mille alla Caldarella ja Merrelli (1997) taksonoomia järgi liigituvad ajaplaneerimine, eesmärkide seadmine, juhiste järgimine ja täitmine, oskus küsimusi esitada, paluda abi jne. Akadeemiliste oskuste kasv viitab programmi raames toimuvale õppimisele ja juhendaja rolli olulisusele. Kuigi programmis on rõhk ettevõtte loomisel ja toote või teenuse turule toomisel, on siiski tegemist eelkõige õpiprotsessiga ja juhendajal on siinjuures täita väga tähtis osa. Üheks põhiliseks õpilasfirmade programmi eesmärgiks on püstitatud ka ajaplaneerimine, mis võimaldab sooritada ülesandeid õigel ajal, järgides programmis ette nähtud ajakava. Erinevalt väikeettevõtetest, kes saavad koostada ise oma ajakava, on 
õpilasfirmadel tegutsemiseks suhteliselt piiratud aeg. Sügisel õpilasfirmaga alustades saavad noored vaid paar kuud tootearenduseks ja turunduseks, sest juba detsembris algavatel laatadel tuleb oma toote ja teenusega välja tulla. See tõstab esikohale ajaplaneerimisoskuse ning survestab programmijärgset tegevust. Viies Euroopa riigis 2016. aastal tehtud uuringu tulemustest selgus, et nii õpetajate kui ka õpilaste üks olulisimaid tulemusi ongi ajaplaneerimisoskuse paranemine (Eide \& Olsvik, 2017). Samuti näitas 2015/2016. aastal Inglismaal korraldatud uuring, et ettevõtlusõppe käigus arenesid õppijate organisatoorsed oskused, sealhulgas ajaplaneerimine ja eesmärkide seadmine (Young Enterprise, 2016).

Caldarella ja Merrelli sotsiaalsete oskuste taksonoomia järgi, mis on uurimuse teoreetiliseks raamistikuks, on olulised enesekehtestamisoskused seotud nii initsiatiivi, enesekindluse, enda esitlemise oskustega kui ka oskusega öelda ei. Tähtsal kohal on eneseanalüüs ja oskus enda positiivseid jooni esile tuua (Caldarella \& Merrell, 1997). Ka 2014/2015. aastal Inglismaal tehtud uuringu tulemustest ilmnes, et õpilasfirmade programmi läbimisel paranes noorte teadlikkus oma võimetest ja oskustest (Young Enterprise, 2015). Üks õpilasfirmade programmi eesmärke on parandada esitlemis- ja suhtlemisoskust, samuti kasvatada enesekindlust ja soodustada initsiatiivi võtmist. Kuna programmis on tähtsal kohal oma idee, toote või teenuse müümine (nt laatadel osalemine või koostööpartneritega kohtumine), siis sellise tegevuse käigus arenevad ühtlasi noorte esitlusoskus ja eneseturundusoskus. Ka 2015/2016. aastal Belgias, Eestis, Itaalias, Lätis ja Soomes tehtud uuringu tulemustest selgus, et õpilasfirmade programmi läbimisel arenes noorte esitlusoskus ning enesekehtestamisega seotud oskused, lisaks olid noored altimad võtma initsiatiivi. Samas uuringus tõid noored esile, et õpilasfirmade programm arendas neis oskust seista oma ideede eest, hoolimata teiste inimeste arvamusest, ja muutis nad oma ideede esitlemisel enesekindlamaks (Eide \& Olsvik, 2017). Siiski ilmnesid selle faktoriga seotud muutused sotsiaalsete oskuste arengus vaid Põlvamaa noortel.

Tartumaa noorte tulemustest selgus, et akadeemilistele oskustele lisaks paranesid nende enesejuhtimisoskused. Caldarella ja Merrelli (1997) käsitluse järgi on selle faktori puhul olulised oskused seotud probleemilahenduse, koostöö, kompromisside ja riskivalmidusega. Õpilasfirmade programmi eesmärke silmas pidades väärib tähtsustamist meeskonna- ja rühmatööoskus. Koostööpartneritega suhtlemisel, meeskonna loomisel ja arendamisel on kompromisside tegemise ning koostööoskused kesksel kohal. Artikli teise autori aastatepikkune kogemus õpilasfirmadega on näidanud, et igas õpilasfirmas esineb probleeme, mistõttu on ootuspärane, et noortel arenevad ka kompromisside tegemise, probleemilahendus- ja läbirääkimisoskused. Ka 2015/2016. aastal Inglismaal korraldatud õpilasfirmade programmi mõju-uuringust selgus, et programm 
toetab noorte probleemilahendus- ning meeskonna- ja koostööoskuste arengut (Young Enterprise, 2016).

Mõnevõrra üllatuslikuna ilmnes uurimistulemustest, et õpilasfirmade programmi läbimisel ei paranenud Võrumaa noorte sotsiaalsed oskused. Autorite arvates võib selle põhjus olla asjaolu, et selle maakonna õpilasfirmade juhendajal oli vaatlusalusel õppeaastal juhendada 15 õpilasfirmat, mistõttu võib oletada, et juhendaja personaalne toetus õpilasfirmadele oli väiksem. Teistes maakondades jäi ühe õpetaja juhendada keskmiselt 2-7 õpilasfirmat, mis on oluliselt väiksem arv. Lisaks kasutasid teiste maakondade (Tartu- ja Põlvamaa) õpilasfirmad mentoreid erasektorist ning osalesid mentoriprogrammides, mis on loodud õpilasfirmade programmi tegevust arvestades või toetavad nende tegevust, nt Tartu Ärinõuandla algatatud õpilasfirmade mentoriprogramm, Tartu Ülikooli pakutavad mentorlustegevused Tartumaa õpilasfirmade toetamiseks, ideekonkurss „Välgatus“, mille raames said Põlvamaa õpilasfirmad endale isikliku mentori, ning „Kaleidoskoop“ Tartumaal. Ideekonkursid panevad rohkem mõtlema selle üle, kas idee on jätkusuutlik, praktiliselt kasutatav ja teostatav või jääbki see vaid pelgalt ideeks. Mentorite kaasamine on eriti vajalik juhul, kui pakutakse mõnd erialaspetsifilist toodet või teenust, mille puhul tulevad kasuks erialased teadmised ja oskused. Ka viies Euroopa riigis tehtud uuringu tulemustest selgus, et noored pidasid mentorite panust väga tähtsaks. Kuna paljudel juhendajatel puudub reaalne kogemus ärimaailmast, siis saavad mentorid just selle lünga täitmisele kaasa aidata. Mentori kaasamine pakub õpilasfirmale spetsiifilisemaid oskusi ja teadmisi (nt müük, suhtlemine, kliendi poole pöördumine, toote tutvustamine), teistmoodi vaatenurka ning tuge mõtlemisel ja lahenduste leidmisel. Mentoriprogramm annab eelnevale lisaks võimaluse teiste kogemustest õppida ning jagada mõtteid ja ideid (Eide \& Olsvik, 2017). Kõike seda arvesse võttes võib oletada, et mentoritel ja toetavatel tegevustel on märkimisväärne mõju noorte sotsiaalsete oskuste arengule.

Uurimistöö raames uurisid autorid noorte hinnanguid selle kohta, mil määral mõjutas õpilasfirmade programm nende isiksusomadusi. Programmiga alustades oli noortel võimalik hinnata viiepalliskaalal enda seitset isiksusomadust: ettevõtlikkust, loovust, uuendusmeelsust, paindlikkust, enesekindlust, vastutustunnet ja sihikindlust. Isiksusomaduste valiku aluseks oli õpilasfirmade programmi juurde kuuluv enesehinnangutest (The Entrepreneurial Skills Pass), mille täitmine on Euroopa riikides õpilasfirmade programmi läbimise kohustuslik osa ning mida täidavad kõik programmi läbivad noored õpilasfirmaga alustades ja lõpetades. Uurimistulemustest selgus, et programmi käigus arenesid noorte endi hinnangul ettevõtlikkuse, loovuse, uuendusmeelsuse ja paindlikkusega seotud isiksusomadused. Kuna õpilasfirma tegemine on võrreldes ärimaailmas toimuvaga suhteliselt lühiajaline protsess (see luuakse 
kooliaasta alguses ja lõpetatakse kooliaasta lõpus, maksimaalselt saab firma tegutseda üheksa kuud), igal aastal luuakse Eestis ligikaudu 300 õpilasfirmat (Eide \& Olsvik, 2017) ning konkurents õpilasfirmade turul on tihe, paneb see õpilasfirmat tegevad noored loovalt mõtlema ning soodustab uuendusmeelsust. Ühtlasi võimaldab see konkurentide seas paremini silma paista ning oma toodet või teenust klientidele ja koostööpartneritele paremini müüa. Ka viies Euroopa riigis tehtud uuringu tulemused näitasid, et kõigis neis suurendas programm noorte loovust. Samuti näitasid selle uuringu tulemused vastutustunde ja enesekindluse kasvu (Eide \& Olsvik, 2017), mis aga ei ilmnenud siinse uurimuse tarbeks korraldatud uuringust. Kuna ajaline piirang ei võimalda noortel tihti teha pikaajalisi plaane ega eri võimalusi läbi proovida, tuleb olla paindlik ja lahendada probleeme vastavalt hetkeolukorrale. Ka Inglismaal tehtud uuringu tulemused näitasid paindlikkuse kasvu (Young Enterprise, 2016). Samamoodi nagu sotsiaalsete oskuste puhul, esinesid ka isiksusomaduste arengus muutused vaid kahe maakonna - Põlva- ja Tartumaa - tulemustes.

Kuna üksnes kogutud andmete põhjal on keeruline teha väga selgeid järeldusi maakondade tulemuste erinevuse kohta, siis tuleks järeluuringus intervjueerida juhendajaid ning välja selgitada võimalikud erinevused nende juhendamispraktikas. Samuti võib selgitada ilmnenud erinevusi õpilasfirmade programmis osalenute motivatsiooni ja üldise atmosfääri abil. Uuringu lisapiiranguna tuleb nimetada kontrollrühma puudumist, mistõttu ei saa täie kindlusega väita, et tekkinud muutused noorte sotsiaalsetes oskustes on põhjustatud vaid programmi läbimisest.

Kokkuvõtteks võib öelda, et uuringuga sai kinnitust arvamus, et õpilasfirmade programm toetab noorte sotsiaalsete oskuste ja isiksusomaduste arengut, võimaldades noortel tulevikus paremini hakkama saada nii tööturule sisenemisel kui ka aktiivse kodanikuna ühiskonda panustamisel. Sotsiaalsete oskuste ja isiksusomaduste arenemisel on tõenäoliselt olulisel kohal ka toetavad tegurid (nt juhendamine, keskkond, perekond), mille mõju praegusel juhul küll ei uuritud, aga millele oleks järeluuringus mõistlik keskenduda.

\section{Kasutatud kirjandus}

Caldarella, P., \& Merrell, K. W. (1997). Common dimensions of social skills of children and adolescents: A taxonomy of positive behaviors. School Psychology Review, 26(2), 264-278.

Chazan, M., Laing, A. F., Davies, D., \& Phillips, R. (2001). Eemaletõmbunud, üksildaste laste ja noorukite abistamine. Tartu: Tartu Ülikooli Kirjastus.

Eesti ettevõtluse kasvustrateegia 2014-2020 (2013). Tallinn: Majandus- ja Kommunikatsiooniministeerium. 
Eide, T. H., \& Olsvik, V. M. (2017). Qualitative case studies of mini-company experiences in five European countries. "If everything is told to you, it is not learning. You have to figure out something on your own". ENRI working paper 04, 2017. Lillehammer: Eastern Norway Research Institute. Retrieved from http://www.ostforsk.no/wp-content/uploads/2017/03/201704_Qualitative_case_ study_of_mini-company_experiences_in-five_European_countries.pdf.

Ettevõtlusõppe edendamise kava „Olen ettevõtlik!“ (2010). Tallinn: Eesti KaubandusTööstuskoda, Ettevõtlusõppe Mõttekoda. Külastatud aadressil http://www.digar.ee/id/nlib-digar:190616.

Final report of the expert group "Education for entrepreneurship": Making progress in promoting entrepreneurial attitudes and skills through primary and secondary education (2004). Brussels: European Comission.

Gresham, F. M., \& Elliot, S. N. (1993). Social skills interventions for children. Behavior Modification, 17(3), 287-313. https://doi.org/10.1177/01454455930173004

Gümnaasiumi riiklik õppekava (2011). Riigi Teataja I, 14.01, 2. Külastatud aadressil https://www.riigiteataja.ee/akt/129082014021.

Keltikangas-Järvinen, L. (2011). Sotsiaalsus ja sotsiaalsed oskused. Tallinn: Koolibri.

Ploom-Zilmer, K. (2013). Kutseõppeasutuste spetsialistide hinnangud mõõduka intellektipuudega noorte sotsiaalsete oskuste omandatuse tasemele kutseõppes (bakalaureusetöö). Tartu: Tartu Ülikool. Külastatud aadressil http://dspace.ut.ee/bitstream/handle/10062/29050/ploom_zilmer_kaili.pdf.

Põhikooli- ja gümnaasiumiseadus (2010). Riigi Teataja I, 41, 240. Külastatud aadressil https://www.riigiteataja.ee/akt/13332410.

Saat, H. (2005). Sotsiaalsed oskused: kontseptsioon ning arendamise ja hindamise võimalused koolis. A. Ots (toim.), Üldoskused - ópilase areng ja selle soodustamine koolis (lk 131-160). Tartu: Tartu Ülikooli Kirjastus.

Zhou, M., \& Ee, J. (2012). Development and validation of the Social Emotional Competence Questionnaire (SECQ). The International Journal of Emotional Education, 4(2), 27-42.

Tegevuskava „Ettevõtlus 2020“ - ettevõtlikkuse taaselavdamine Euroopas (2013). Euroopa Parlament. Külastatud aadressil

http://www.europarl.europa.eu/sides/getDoc.do?pubRef=-//EP//NONSGML+ $\mathrm{TA}+\mathrm{P} 7-\mathrm{TA}-2013-0512+0+\mathrm{DOC}+\mathrm{PDF}+\mathrm{V} 0 / / \mathrm{ET}$.

Tropp, K., \& Saat, H. (2010). Õpilaste suhted eakaaslaste ning täiskasvanutega ja sotsiaalsete oskuste areng. E. Kikas (toim.), Õppimine ja õpetamine esimeses ja teises kooliastmes (lk 61-87). Tartu: Haridus- ja Teadusministeerium.

Vestergaard, L., Moberg, K., \& Jørgensen, C. (Eds.) (2012). Impact of entrepreneurship education in Denmark - 2011. The Danish Foundation for Entrepreneurship. Retrieved from http://www.cise.es/wp-content/uploads/2013/03/5.-impact_of_ entrepreneurship_education_in_denmark_2011.pdf.

Virnas, J. (2017). Opilasfirmade programmi mõju noorte sotsiaalsete oskuste arengule noorte hinnangul (lõputöö). Tartu: Tartu Ülikool.

Walker, H. M., Colvin, G., \& Ramsey, E. (1995). Antisocial behavior in school: Strategies and best practices. Pacific Grove: Books/Cole Publishing Company.

Wilson, K. (2008). Entrepreneurship education in Europe - Entrepreneurship and higher education. In J. Potter (Ed.), Entrepreneurship and higher education (pp. 119-137). Paris: OECD Publishing. 
Young Enterprise (2015). Company programme 2014-15 impact report. Retrieved from https://www.young-enterprise.org.uk/wp-content/uploads/2014/09/CP-201415-Impact-Report.pdf.

Young Enterprise (2016). Company programme 2015-16 impact report. Retrieved from https://www.young-enterprise.org.uk/wp-content/uploads/2014/09/YEImpact-Report-2016-FINAL-1.pdf. 
Lisa. Küsimustik õpilasfirmade programmis osalevatele noortele

Hea õpilasfirma liige!

Olen ... üliõpilane ning viin läbi uuringut, mille raames uuritakse noorte sotsiaalsete oskuste arengut läbi õpilasfirmade programmi. Selle väljaselgitamiseks palun Teil täita järgnev küsimustik.

Uuringus osalevad Põlva-, Tartu- ja Võrumaal 2016/2017. õppeaastal tegutsevate õpilasfirmade liikmed. Kogutud andmeid kasutatakse ainult käesoleva uuringu raames. Kõiki kogutud andmeid kajastatakse ainult üldistatud kujul ning tagades iga osaleja anonüümsuse.

Loodan väga, et nõustute panustama käesolevasse sotsiaalsete oskuste uuringusse. Kui Teil tekib uuringuga seoses mõningaid küsimusi, siis võtke julgesti ühendust.

Ette tänades

...

Sugu .... ...M

Vanus

Maakond, kus sinu õpilasfirma tegutseb ...Põlvamaa ... Tartumaa ... Võrumaa

Palun hinda, kuivõrd õiged on järgmised väited sinu puhul.

Vastuste skaala: 1-5 (1 - see ei ole minu puhul õige; 5 - on minu puhul väga õige).

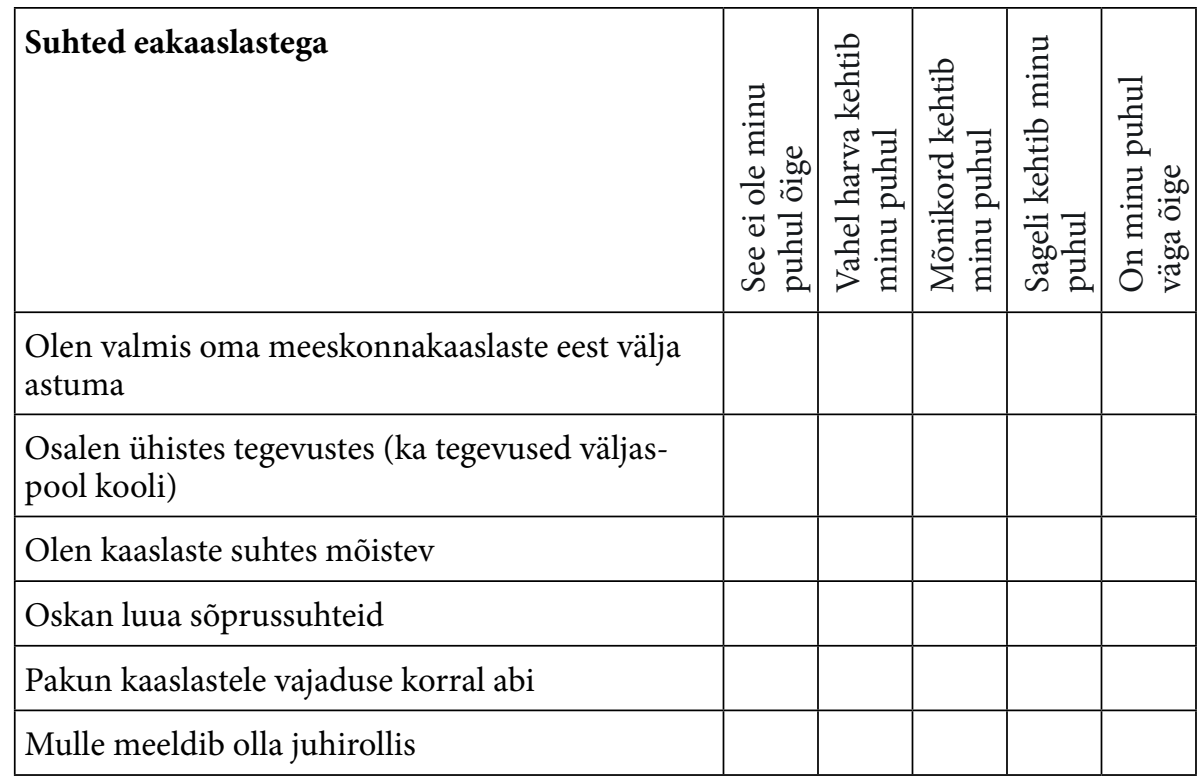




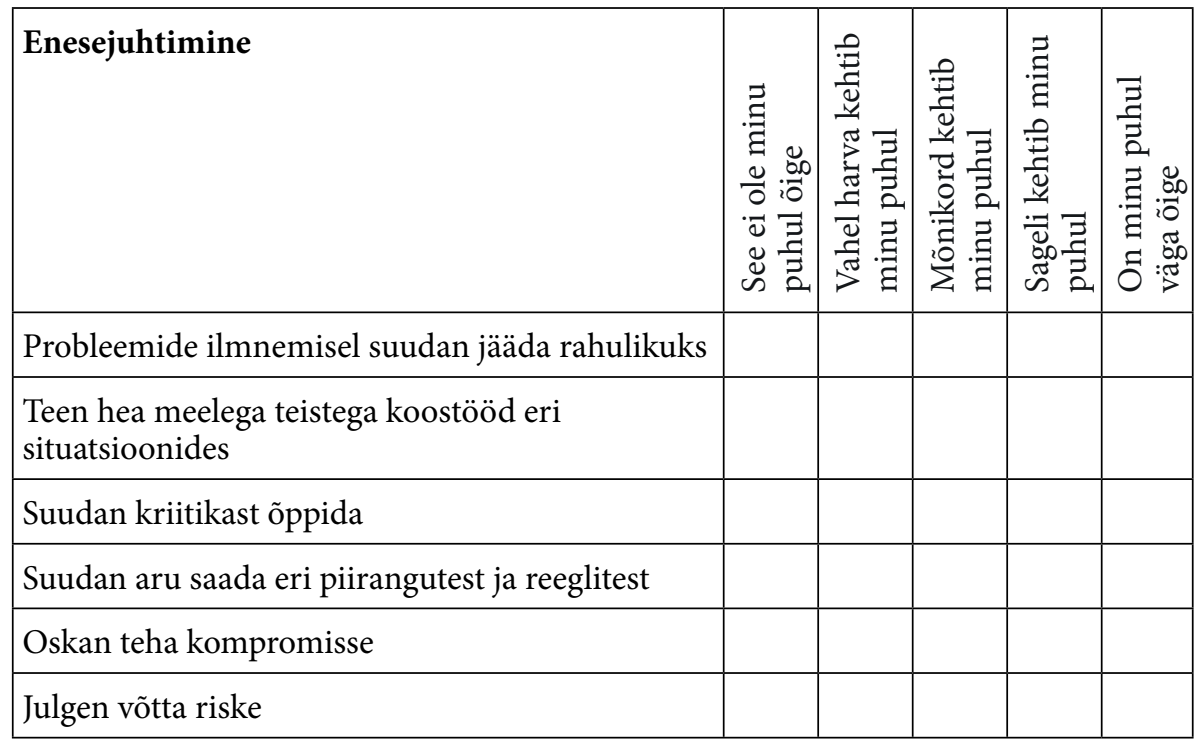

\begin{tabular}{|c|c|c|c|c|c|}
\hline Akadeemilised oskused & 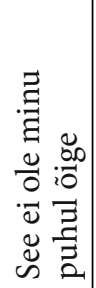 & 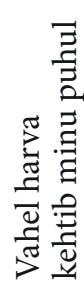 & 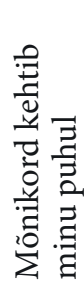 & 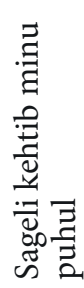 & 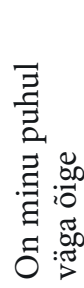 \\
\hline \multicolumn{6}{|l|}{ Küsimuste tekkimisel julgen küsida abi } \\
\hline \multicolumn{6}{|c|}{$\begin{array}{l}\text { Hoolimata kaaslaste mõjutustest, suudan jätkata } \\
\text { tööd }\end{array}$} \\
\hline \multicolumn{6}{|l|}{ Oskan esitada asjakohaseid küsimusi } \\
\hline \multicolumn{6}{|l|}{ Täidan endale määratud tööülesandeid } \\
\hline \multicolumn{6}{|l|}{ Oskan oma aega hästi planeerida } \\
\hline Oskan seada eesmärke oma tegevusteks & & & & & \\
\hline
\end{tabular}

\begin{tabular}{|c|c|c|c|c|c|}
\hline Kuuletumine & 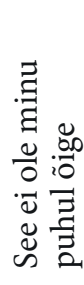 & 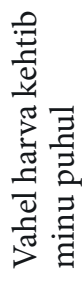 & 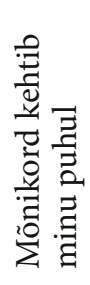 & 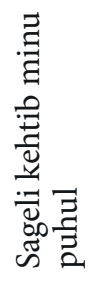 & 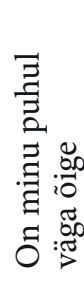 \\
\hline \multicolumn{6}{|l|}{ Suudan aru saada eri juhenditest } \\
\hline \multicolumn{6}{|l|}{ Järgin alati reegleid } \\
\hline Viin alati alustatud ülesanded lõpuni & & & & & \\
\hline
\end{tabular}




\begin{tabular}{|c|c|c|c|c|c|}
\hline Enesekehtestamisoskused & 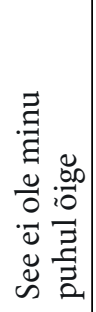 & 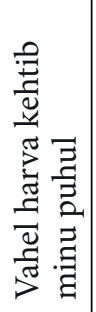 & 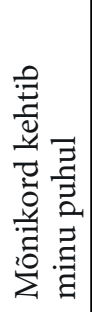 & 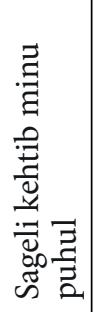 & 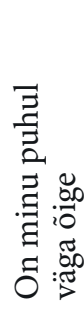 \\
\hline \multicolumn{6}{|c|}{ Olen alati oma tegevustes enesekindel } \\
\hline \multicolumn{6}{|c|}{ Sõbrunen kergesti teiste inimestega } \\
\hline \multicolumn{6}{|l|}{ Oskan öelda „ei“ } \\
\hline \multicolumn{6}{|l|}{ Oskan ennast esitleda } \\
\hline \multicolumn{6}{|c|}{ Oskan tuua välja oma positiivsed jooned } \\
\hline \multicolumn{6}{|l|}{ Tean enda tugevaid ja nõrku külgi } \\
\hline \multicolumn{6}{|c|}{ Oskan oma seisukohti argumenteerida } \\
\hline Suudan välja mõelda uusi ideid & & & & & \\
\hline
\end{tabular}

Palun hinda viiepalliskaalal järgmisi isiksusomadusi.

Vastuste skaala: 1-5 (1 - väga madal; 5 - väga kõrge).

\begin{tabular}{|c|c|c|c|c|c|}
\hline Isiksusomadused & 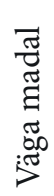 & 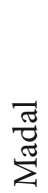 & 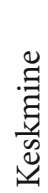 & $\begin{array}{l}\mathscr{D} \\
: 0 \\
0\end{array}$ & 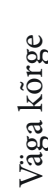 \\
\hline Ettevõtlikkus & & & & & \\
\hline Loovus & & & & & \\
\hline Uuendusmeelsus & & & & & \\
\hline Paindlikkus & & & & & \\
\hline Enesekindlus & & & & & \\
\hline Vastutustunne & & & & & \\
\hline Sihikindlus & & & & & \\
\hline
\end{tabular}

Suur tänu vastamast! 


\title{
The impact of the student companies programme on the development of social skills of the youth
}

\author{
Katrin Saks ${ }^{a 1}$, Janeli Virnas ${ }^{a}$ \\ ${ }^{a}$ Institute of Education, University of Tartu
}

\section{Summary}

\section{Introduction}

The issues of youth unemployment refer to the fact that the skills acquired at school are becoming increasingly important. Social skills are considered important when entering the job market and people with adequate social skills are highly valued (Keltikangas-Järvinen, 2011). Therefore, it is essential to investigate whether and how the student companies programme supports youngsters' social skills that are increasingly important when entering professional life and becoming an active citizen.

As no solid definition for social skills can be found in the literature, the study will mainly handle approaches that cover social skills related to entrepreneurship. According to Walker and colleagues (1995), social skills are a collection of competences that help initiate and preserve positive relationships and enhance peer acceptance, and allow the individual to adapt more effectively in a larger social environment. According to Gresham and Elliot (1993), social skills are socially acceptable learned skills that allow the individual to communicate with others in the way that evokes positive reactions and helps avoid negative reactions.

As social skills are defined differently, their classifications also vary. The current study relies on the taxonomy suggested by Caldarella and Merrell (1997). According to their classification, social skills are divided into five categories: peer relations, self-management, academic skills, compliance, and assertion skills (ibid.).

Gresham and Elliot (1993) consider the development of social skills as one of the most important outputs of the learning process. In addition to academic teaching methods, social skills can also be taught experientially using methods of experiential and active learning. These methods develop knowledge and social skills through experience and exploration, and link the different fields of life (Ploom-Zilmer, 2013). The student companies programme handled in the current work is also a practical outcome of active learning of Entrepreneur- 
ship and Economy. There are two essential components when defining the concept of an Entrepreneurship programme: entrepreneurship as an attitude/ personal trait, and knowledge and skills. An entrepreneurial person thinks creatively, he initiates with confidence, acts wisely and is caringly responsible (Ettevõtlusõppe edendamise kava..., 2010). The goal of student companies is to acquire entrepreneurial skills and to develop entrepreneurial spirit via practical activities. The sub-goals of a student company include completion of the life cycle of a business while taking the role of an entrepreneur and a leader of a company, developing creativity and group work skills, building responsibility, learning time management, developing skills of research (market research), presentation and communication (Eide \& Olsvik, 2017).

This research aimed at investigating the increase in social skills after completing student companies programme in Tartu, Võru and Põlva County. The research question was posed as follows: whether and to what extent does the student companies programme support the development of social skills and personality traits?

\section{Methodology}

The study sample who participated in the student companies programme comprised 10th-12th grade students from three South-Estonian counties - Tartu, Põlva and Võru County. The pre-test was responded by 117 people, the number of respondents in the post-test was 112 . The number of people who responded to both, the pre- and post-test was 94 , a total of $43 \%$ of the study sample. 21 students came from Põlva County, 30 from Tartu County, and 43 from Võru County. $61.7 \%$ of the sample were girls, $38.3 \%$ were boys. The respondents' average age was 17.01 years $(S D=0.31)$.

The study was conducted using quantitative methods. Pre- and post-testing was conducted using a web-based questionnaire based on a Likert-type scale including thirty nine questions in three sub-divisions: objective characteristics (gender, age, county), self-reported statements divided into five categories: peer relations, self-management, academic skills, compliance, assertion skills, and personality traits: entrepreneurial spirit, creativity, innovation, flexibility, selfconfidence, responsibility and perseverance.

Data analysis was conducted using the software programmes Excel and SPSS 24. The data was analysed using descriptive and comparative statistics, ANOVA, and a paired samples t-test was used to evaluate the change in the social skills of the participants. 


\section{Results and conclusions}

To reveal potential differences in the students' social skills between the three counties, their pre-test results were compared. As ANOVA revealed no statistically significant differences in any of the factors related to the social skills or personality traits, it could be claimed that at the beginning of the student companies programme the students from the three counties did not distinguish in their social skills. In order to investigate whether and how much participating in the student companies programme supported the development of the students' social skills, a paired samples t-test was conducted to compare the means of pre- and post-tests.

The paired samples $t$-test showed statistically significant improvement in self-management and academic skills among the students of Tartu County and academic skills and assertion skills by the students of Põlva County. However, the only county that revealed no statistically significant change based on the paired samples $t$-test was Võru County.

Also the development of various entrepreneurship-related personality traits connected to the student companies programme was explored. Similarly to the first part of the analysis, only two counties, Tartu County and Põlva County, showed statistically significant change in the personality traits. The results of the paired samples t-test revealed significant improvement in entrepreneurship, creativity and flexibility among the youth of Tartu County. In Põlva County, the student companies programme supported the development of creativity and innovation of the youth. The data on the youth of Vorru County did not reveal statistically significant change in the development of personality traits. The differences between the findings of the three counties can be explained by the situation that in Tartu and Põlva County, in addition to the general student companies programme, the youth also had access to additional activities, such as mentoring and idea competitions. Therefore, it might be assumed that various supportive activities are essential to this programme while developing participants' social as well as entrepreneurial skills. No change in social skills or personality traits among the youth in Vorru County, in the context of the student companies programme, might be related to the tutors having too many students to supervise. In addition, no mentors were involved in the activities of the student companies in Vorru County and the students did not participate in other supportive activities during the school year.

In conclusion, the student companies programme supports the development of social skills and personality traits according to the estimates of the young people. It is important as in the future, it enables them to effectively enter the job market as well as contribute to the society as an active citizen. 
However, in the development of social skills the supportive factors, such as mentoring, environment, etc., which were not studied in the scope of this work, are probably important factors as well, and the author's suggestion is to focus on these more thoroughly in the follow-up study.

Keywords: student companies, social skills, personal characteristics 